\title{
Article \\ The Roles of IL-22 and Its Receptor in the Regulation of Inflammatory Responses in the Brain
}

\author{
Dahae Lee ${ }^{1}$, Hyejung Jo ${ }^{1}$, Cheolhyeon Go ${ }^{1}{ }^{\mathbb{D}}$, Yoojin Jang ${ }^{1}$, Naghyung Chu ${ }^{2}$, Suhyun Bae ${ }^{1}$, Dongmin Kang ${ }^{3}$, \\ Yejin Kim ${ }^{1,4, *}$ and Jae Seung Kang ${ }^{1,4, * \mathbb{B}}$
}

1 Laboratory of Vitamin C and Antioxidant Immunology, Department of Anatomy and Cell Biology, Seoul National University College of Medicine, Seoul 03080, Korea; ddhh12345@snu.ac.kr (D.L.); luv_jo@snu.ac.kr (H.J.); rhcjfgus@snu.ac.kr (C.G.); pierce52@snu.ac.kr (Y.J.); bsh9706@gmail.com (S.B.)

2 Department of Biology, College of Arts and Sciences, Emory University, Atlanta, GA 30322, USA; nchu0423@gmail.com

3 Department of Psychological and Brain Sciences, College of Arts and Sciences, Boston University, Boston, MA 02215, USA; dong1109@bu.edu

4 Medical Research Center, Institute of Allergy and Clinical Immunology, Seoul National University, Seoul 03080, Korea

* Correspondence: bbambaya921@snu.ac.kr (Y.K.); genius29@snu.ac.kr (J.S.K.)

Citation: Lee, D.; Jo, H.; Go, C.; Jang, Y.; Chu, N.; Bae, S.; Kang, D.; Kim, Y.; Kang, J.S. The Roles of IL-22 and Its Receptor in the Regulation of Inflammatory Responses in the Brain Int. J. Mol. Sci. 2022, 23, 757. https:// doi.org/10.3390/ijms23020757

Academic Editor: Derek Pociask

Received: 7 December 2021

Accepted: 10 January 2022

Published: 11 January 2022

Publisher's Note: MDPI stays neutral with regard to jurisdictional claims in published maps and institutional affiliations.

Copyright: (C) 2022 by the authors. Licensee MDPI, Basel, Switzerland. This article is an open access article distributed under the terms and conditions of the Creative Commons Attribution (CC BY) license (https:// creativecommons.org/licenses/by/ $4.0 /)$.

\begin{abstract}
Interleukin (IL)-22 is a potent mediator of inflammatory responses. The IL-22 receptor consists of the IL-22R $\alpha$ and IL-10R $\beta$ subunits. Previous studies have shown that IL-22R $\alpha$ expression is restricted to non-hematopoietic cells in the skin, pancreas, intestine, liver, lung, and kidney. Although IL-22 is involved in the development of inflammatory responses, there have been no reports of its role in brain inflammation. Here, we used RT-PCR, Western blotting, flow cytometry, immunohistochemical, and microarray analyses to examine the role of IL-22 and expression of IL-22R $\alpha$ in the brain, using the microglial cell line, hippocampal neuronal cell line, and inflamed mouse brain tissue. Treatment of BV2 and HT22 cells with recombinant IL-22 increased the expression levels of the pro-inflammatory cytokines IL- 6 and TNF- $\alpha$, as well as cyclooxygenase (COX)-2 and prostaglandin E2. We also found that the JNK and STAT3 signaling pathways play an important role in IL-22-mediated increases in inflammatory mediators. Microarray analyses revealed upregulated expression of inflammation-related genes in IL-22-treated HT22 cells. Finally, we found that IL-22R $\alpha$ is spontaneously expressed in the brain and is upregulated in inflamed mouse brain. Overall, our results demonstrate that interaction of IL-22 with IL-22R $\alpha$ plays a role in the development of inflammatory responses in the brain.
\end{abstract}

Keywords: IL-22; IL-22R $\alpha$; inflammation; BV2; HT22

\section{Introduction}

Interleukin (IL)-22, a member of the IL-10 cytokine family, is produced by several subsets of lymphocytes, including CD4 + T helper 17 (Th17) and Th22 cells, natural killer cells, CD8+ cytotoxic T cells, $\gamma \delta \mathrm{T}$ cells, and lymphoid tissue inducer-like cells [1-5]. In addition, it has been reported recently that IL-22 is also produced by activated macro-phages [6]. Although IL-22 has an anti-inflammatory role in inflammatory bowel diseases, it can promote inflammatory conditions in autoimmune diseases such as rheumatoid arthritis (RA), Crohn's disease, and various skin diseases [7,8]. Also, IL-22 upregulates the production of acute-phase proteins in hepatoma cells, suggesting that it is involved in the regulation of inflammatory responses [4]. The biological role of IL-22 was originally described in hepatoma cells, keratinocytes, and pancreatic acinar cells, and it was subsequently reported to be involved in the pathogenesis of numerous inflammatory diseases, notably psoriasis [9-11].

The IL-22 receptor (IL-22R) is a heterodimer of IL-22R $\alpha$ and IL-10R $\beta$ subunits [5]. IL- $10 \mathrm{R} \beta$ is expressed in a wide variety of cells, including immune cells, whereas IL-22R $\alpha$ 
expression is thought to be limited to epithelial cells in organs such as the lung, kidney, colon, pancreas, and skin $[4,12,13]$. For this reason, the roles of IL-22R $\alpha$ have typically been studied using non-hematopoietic organs [14]. These studies have shown that binding of IL-22 to IL-22R $\alpha$ induces activation of Janus kinase 1 (JAK1), and the signal transducers and activators of transcription protein 3 (STAT3) and STAT5 pathways, as well as MAP kinase pathways such as the extracellular signal regulated kinase (ERK1/2), c-Jun N-terminal kinase (JNK), and p38 pathways [2,15-17].

To our knowledge, there have been no reports describing expression of IL-22R $\alpha$ in the brain. Therefore, we examined both the role of IL-22 and expression of IL-22R $\alpha$ in the brain using the BV2 microglial cell line, HT22 hippocampal neuronal cell line, and experimentally inflamed mouse brain tissue [18-20]. As the resident macrophages of the central nervous system (CNS), microglia play an important role in the development of inflammatory responses in the brain $[19,21]$. These specialized cells are generally considered to originate from bone marrow-derived monocytes, and are exquisitely sensitive to brain diseases and injury, altering their morphology and phenotype to adopt an activated state in response to pathophysiological brain insults [22-24]. Activated microglia display retracted processes and enlarged cell bodies, and become proliferative at the injured brain site $[18,22,25]$. The cytotoxic effects of microglia and their inflammatory roles mediated through the production of IL- 6 , IL- $1 \beta$, and TNF- $\alpha$ implicate them in a variety of pathological states $[26,27]$. Activated microglia release various bioactive molecules, including nitric oxide and reactive oxygen species. In addition, cyclooxygenase-2 (COX-2) is an enzyme that produces prostaglandin E2 (PGE2), a major inducer of inflammatory processes in the hippocampus [28-31]. Hence, we examined the effects of IL-22 on IL-6, TNF- $\alpha$, COX-2, and PGE2 expression in mouse brain cell lines. We also used microarray analyses to identify the effects of IL-22 on the expression levels of inflammatory genes in HT22 cells.

\section{Results}

2.1. IL-22R Is Constitutively Expressed in BV2 Murine Microglial Cells, HT22 Hippocampal Neuronal Cells, and Mouse Brain Tissue

It is known that IL-22 shows its activity through the binding with IL-22R composed of IL-22R $\alpha$ and IL-10R $\beta$. The expression of IL-22R $\alpha$ is induced and increased under inflammatory condition. IL-10R $\beta$ is constitutively expressed regardless with inflammation and plays a crucial role for signal transduction through IL-22R after dimerization with IL-22R $\alpha$. RT-PCR and Western blotting analyses revealed that IL-22R $\alpha$ is expressed endogenously in BV2 murine microglial cells and HT22 hippocampal neuronal cells and IL-10R $\beta$ is constitutively expressed (Figure 1A,B). A flow cytometry analysis also confirmed that IL-22R $\alpha$ is expressed on the surface of BV2 and HT22 cells, as well as on that of Hepa1c1c7 murine hepatoma cells (used as a positive control; Figure 1C). In addition, an immunohistochemical analysis revealed that IL-22R $\alpha$ is constitutively expressed in mouse brain tissues, especially the hippocampus and cerebellum, and its expression is increased by inflammation (Figure 1D). It is known that IL-22 shows its activity through the binding with IL-22R composed of IL-22Ra and IL-10Rb. 
A

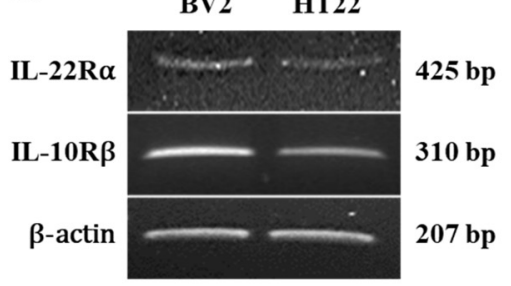

D

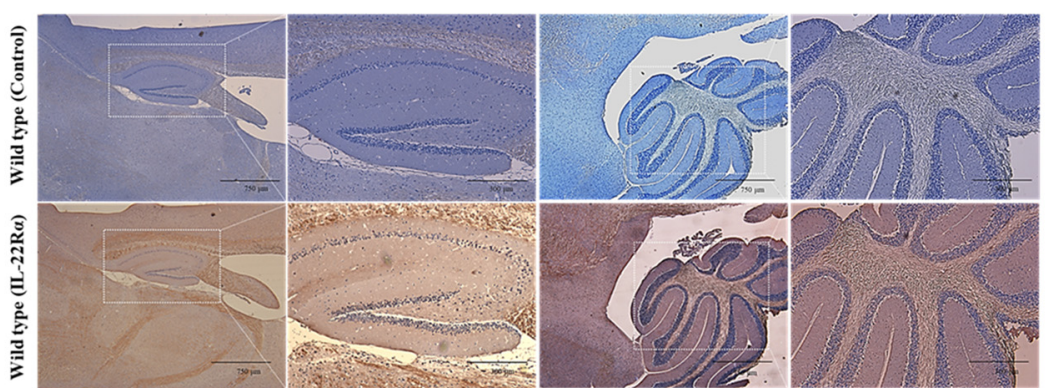

B

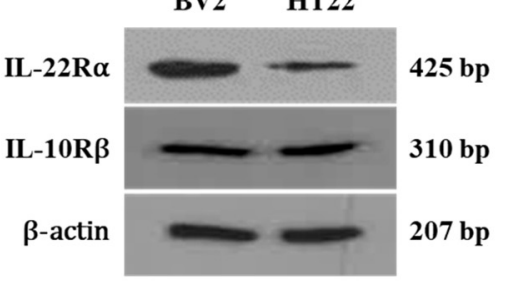

C

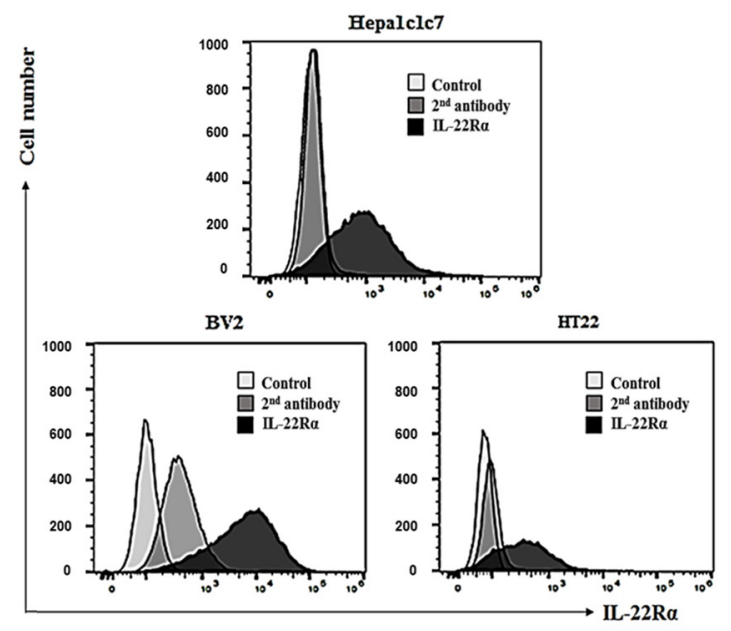

Figure 1. IL-22R $\alpha$ is constitutively expressed in BV2 and HT22 cells and mouse brain tissue. (A) RTPCR analyses of IL-22R $\alpha$ and IL-10R $\beta$ in BV2 and HT22 cells. Total RNA was extracted from cells $\left(1 \times 10^{6}\right)$, and RT-PCR was performed using specific primers for IL-22R $\alpha$ and IL-10R $\beta$, as described in the Materials and Methods. (B) Western blot analyses of IL-22R $\alpha$ and IL-10R $\beta$ in BV2 and HT22 cells. Protein was extracted from $1 \times 10^{6}$ cells and analyzed with -IL-22R $\alpha$ Ab and anti-IL-10R $\beta$ Ab, as described in the Materials and Methods. $\beta$-actin was used as a loading control. (C) Flow cytometry analyses of IL-22R $\alpha$ in BV2, HT22, and Hepa1c1c7 cells. For each sample, $1 \times 10^{5}$ cells were collected, processed as described in the Materials and Methods, and then stained with an anti-mouse IL-22R $\alpha$ antibody $\left(2.5 \mu \mathrm{g} / 10^{6}\right.$ cells $)$ as a primary antibody, and FITC-conjugated anti-rabbit Ab was used as a secondary antibody. IL-22R $\alpha$ expression was analyzed as described in the Materials and Methods. (D) Immunohistochemical analysis of IL-22R $\alpha$ expression in mouse brain. Paraffin-embedded tissues were sectioned with $4 \mu \mathrm{m}$ thickness and incubated with a primary antibody against IL-22R $\alpha$ and then with a biotinylated anti-rabbit antibody. ABC solution was loaded onto the sections for $30 \mathrm{~min}$ and a DAB kit was used for chromogenic detection. (A-D) Results are representative of three independent experiments.

\subsection{The Interaction of IL-22 with IL-22R $\alpha$ Induces Proinflammatory Cytokine Production in BV2 and HT22 Cells}

Since IL-22 is an important pro-inflammatory cytokine, we investigated whether it induces the production of IL- 6 and TNF- $\alpha$ in BV2 and HT22 cells via interaction with IL-22R $\alpha$ [14]. As shown in Figure 2A, IL-22 treatment increased TNF- $\alpha$ production significantly in both cell lines. COX-2 is rarely expressed in steady state, but it is rapidly upregulated under inflammatory conditions. For this reason, we examined the effects of IL-22 treatment ( $20 \mathrm{ng} / \mathrm{mL}$ ) for $1,3,6$, or $12 \mathrm{~h}$ on COX-2 mRNA expression in BV2 and HT22 cells. RT-PCR analyses revealed that COX-2 mRNA expression was increased remarkably in both cell lines at 1 and $6 \mathrm{~h}$ after IL-22 treatment (Figure 2B). In addition, Western blotting analyses revealed that COX-2 protein levels were increased significantly in both cell lines $24 \mathrm{~h}$ after IL-22 treatment (Figure 2C). Next, the effect of exposure to IL-22 (20 ng/mL) for 12 or $24 \mathrm{~h}$ on PGE2 production was examined by ELISA. As expected, PGE2 production by BV2 and HT22 cells was increased significantly at 24 and $48 \mathrm{~h}$ after the treatment (Figure 2D). To examine whether IL-22 increases PGE2 production via the activation of COX-2, PGE2 production was measured after the treatment of NS-398, a specific inhibitor of COX-2, on both cells. As a result, the IL-22-induced increase in PGE2 production was attenuated by the treatment of NS-398 (Figure 2E). 
A

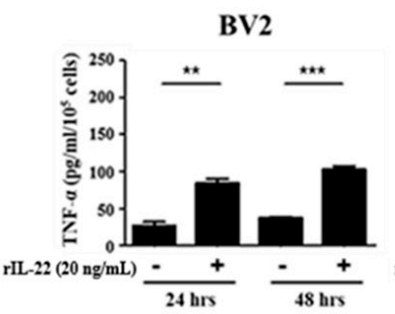

C

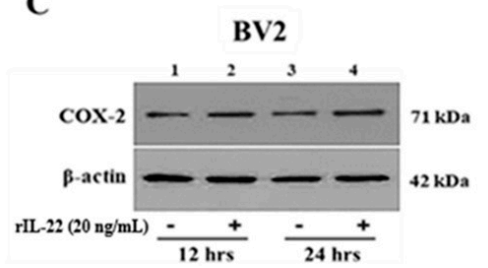

HT22

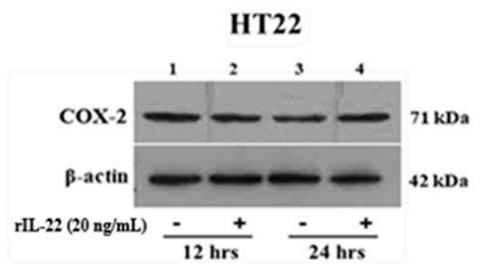

HT22

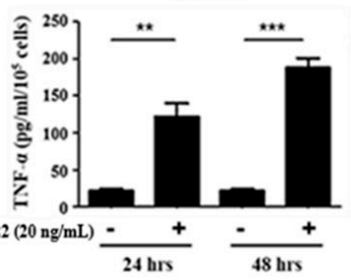

B

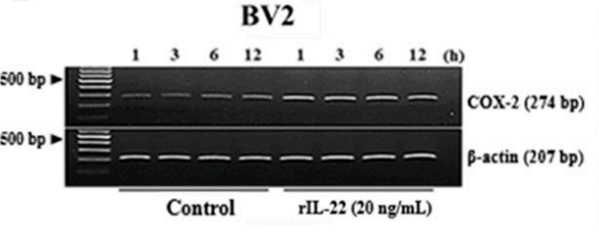

Control

HT22

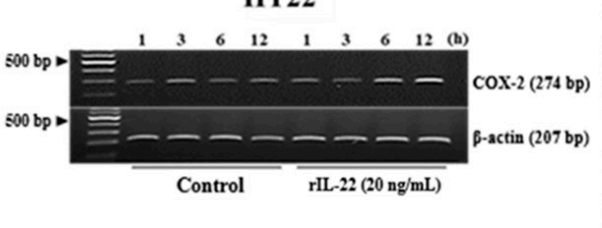

D

BV2
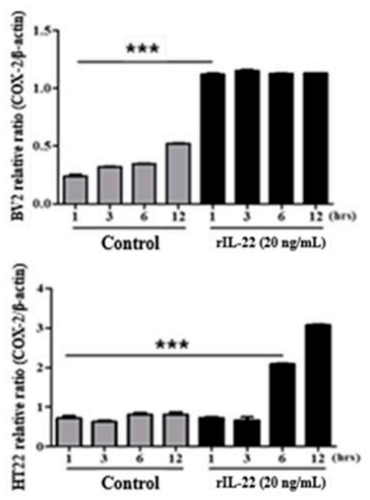

HT22
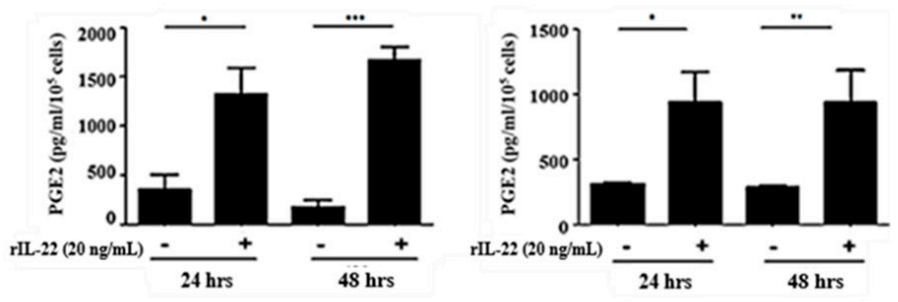

E

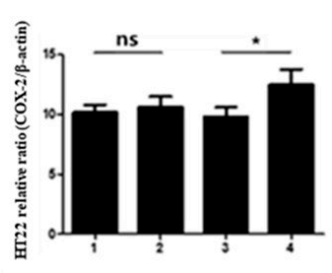

BV2

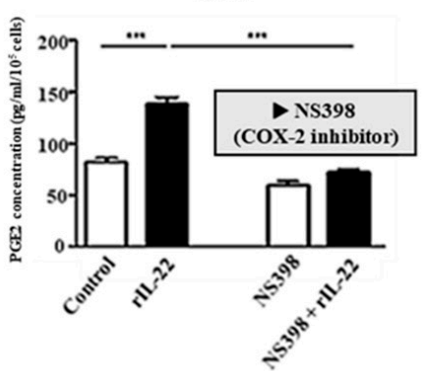

HT22

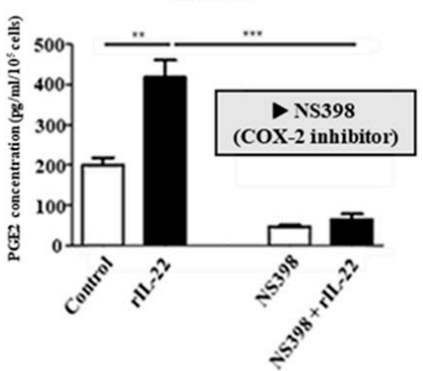

Figure 2. The interaction between IL-22 and IL-22R $\alpha$ induces pro-inflammatory cytokine production in BV2 and HT22 cells. (A) ELISA-based analysis of TNF- $\alpha$ in the supernatants of BV2 and HT22 cells treated with or without IL-22 $(20 \mathrm{ng} / \mathrm{mL})$ for 24 or $48 \mathrm{~h}$. ${ }^{* *} p<0.01$; ${ }^{* *} p<0.001$. (B) RT-PCR analysis of COX-2 expression in BV2 and HT22 cells treated with or without IL-22 $(20 \mathrm{ng} / \mathrm{mL})$ for $1,3,6$, or $12 \mathrm{~h}$. Relative intensity was analyzed by ImageJ software. All results were representative of at least three independent experiments. Values were presented as the mean $\pm \mathrm{SD}$. Significance ( $p$-value) was determined by $t$-test, ${ }^{* * *} p<0.001$. (C) Western blot analysis of COX-2 expression in BV2 and HT22 cells treated with or without IL-22 $(20 \mathrm{ng} / \mathrm{mL})$ for 12 or $24 \mathrm{~h}$. Relative intensity was analyzed by ImageJ software. ${ }^{*} p<0.05$; ${ }^{* *} p<0.01$; ns, not significant. (D) ELISA-based analysis of PGE2 in the supernatants of BV2 and HT22 cells treated with or without IL-22 $(20 \mathrm{ng} / \mathrm{mL})$ for 24 or 48 h. ${ }^{*} p<0.05 ;{ }^{* *} p<0.01 ;{ }^{* * *} p<0.001$. (E) ELISA-based analysis of PGE2 in the supernatants of BV2 and HT22 cells treated with or without IL-22 $(20 \mathrm{ng} / \mathrm{mL})$ and/or NS-398 $(40 \mu \mathrm{M})$ for $24 \mathrm{~h}$. ** $p<0.01 ;{ }^{* *} p<0.001$. 


\subsection{The JNK and STAT3 Signaling Pathways Play an Important Role in IL-22-Induced} Proinflammatory Cytokine Production in BV2 and HT22 Cells, Respectively

In view of the fact that IL-22 induces the production of pro-inflammatory cytokines, we sought to determine which signaling pathways are involved in this response. To this end, BV2 and HT22 cells were pretreated with SP600125 $(20 \mu \mathrm{M})$, a specific inhibitor of JNK, and with S3I-201 $(50 \mu \mathrm{M})$, a specific inhibitor of STAT3, prior to treatment with IL-22. RT-PCR analyses revealed that SP600125 inhibited IL-22-induced TNF- $\alpha$ expression in BV2 cells, and that S3I-201 inhibited TNF- $\alpha$ expression in HT22 cells (Figure 3A). These findings were also confirmed by ELISA (Figure 3B). In addition, IL-22 treatment $(20 \mathrm{ng} / \mathrm{mL}$ ) increased the phosphorylation of JNK in BV2 cells (Figure 3C) and the phosphorylation of STAT3 (Figure 3D) in HT22 cells.

A

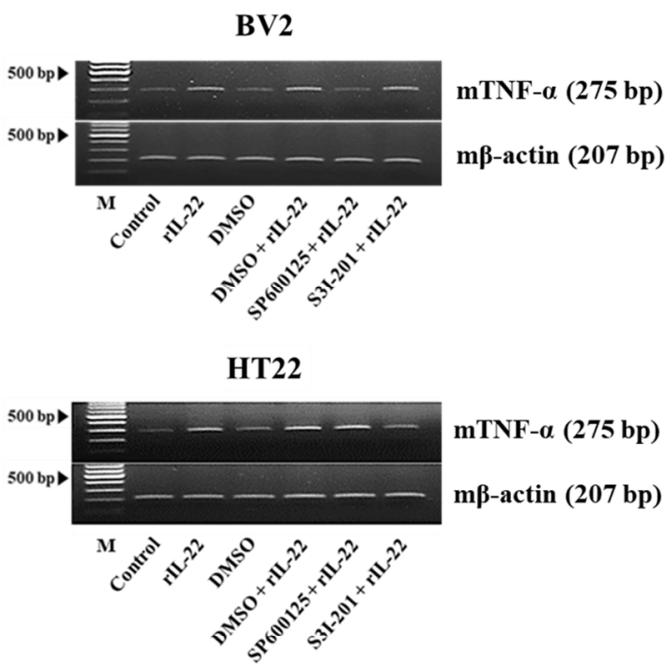

B

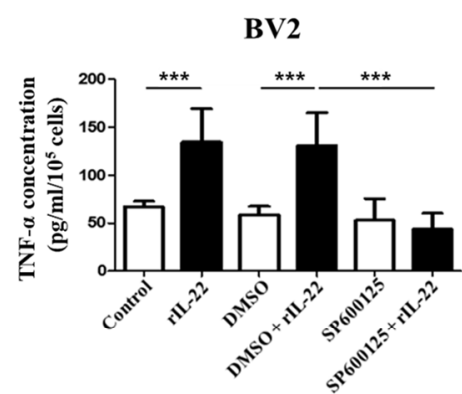

C

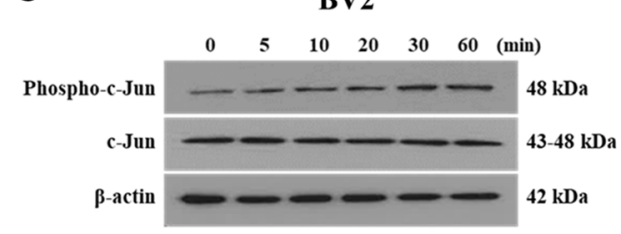

D

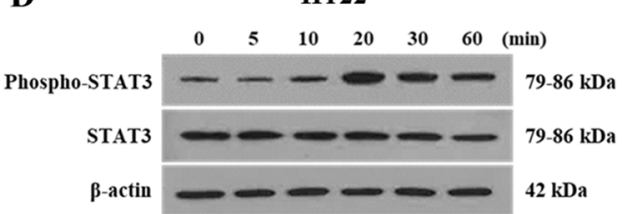

HT22
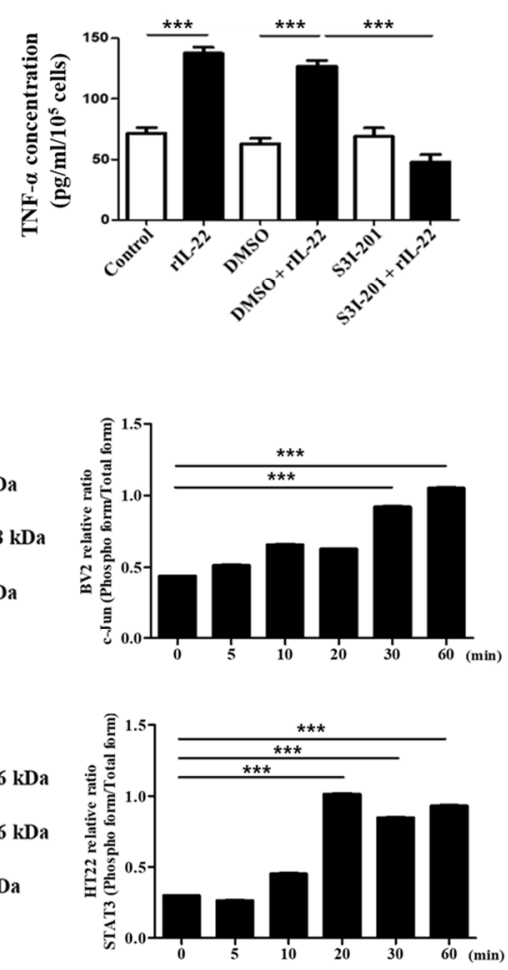

Figure 3. The JNK and STAT3 signaling pathways play an important role in IL-22-mediated inflammatory cytokine production by BV2 and HT22 cells, respectively. (A) RT-PCR analyses of TNF- $\alpha$ in cells that were pretreated with DMSO (vehicle control), SP600125 $(20 \mu \mathrm{M})$, and S3I-201 $(50 \mu \mathrm{M})$ for $1 \mathrm{~h}$ prior to treatment with IL-22 (20 ng/mL) for $12 \mathrm{~h}$. (B) ELISA-based analysis of TNF- $\alpha$ in the supernatants of cells that were pretreated with DMSO (vehicle control), SP600125 $(20 \mu \mathrm{M})$, or and S3I-201 $(50 \mu \mathrm{M})$ for $1 \mathrm{~h}$ prior to treatment with IL-22 $(20 \mathrm{ng} / \mathrm{mL})$ for $48 \mathrm{~h}$. ${ }^{* * *} p<0.001$. (C) Immunoblot analyses of c-Jun and phosphorylated c-Jun in BV2 cells that were pretreated with SP600125 $(20 \mu \mathrm{M})$ and then treated with IL-22 (20 ng/mL) for 0, 5, 10, 20, 30, or $60 \mathrm{~min}$. Relative intensity was analyzed by Image software. All results were representative of at least three independent experiments. Values were presented as the mean \pm SD. Significance ( $p$-value) was determined by $t$-test, ${ }^{* * *} p<0.001$. (D) Immunoblot analyses of STAT3 and phosphorylated STAT3 in HT22 cells that were pretreated with S3I-201 $(50 \mu \mathrm{M})$ and then treated with IL-22 $(20 \mathrm{ng} / \mathrm{mL})$ for $0,5,10,20,30$, or $60 \mathrm{~min}$. (A,C,D) Results are representative of three independent experiments. Relative intensity was analyzed by ImageJ software. All results were representative of at least three independent experiments. Values were presented as the mean \pm SD. Significance ( $p$-value) was determined by $t$-test, ${ }^{* * *} p<0.001$. 


\subsection{IL-22R $\alpha$ Expression Is Increased in the Gulo (-/) Mouse Brain upon Inflammation}

In our previous study [32], we used Gulo (-/-) mice lacking vitamin C supplementation for 5 weeks as a model for spontaneous brain inflammation, and found that vitamin $C$ deficiency is related to defects in both motor and memory functions and the pathogenesis of neurodegenerative disorders, such as Huntington's and Parkinson's diseases. Therefore, we used vitamin C-deficient mice to examine the effects of inflammation on IL-22R $\alpha$ expression in the brain. As shown in Figure 4A,B, IL-22R $\alpha$ expression was increased in the cerebellum white matter region and the hippocampus $\mathrm{CA} 1$ region during the inflammatory response induced by vitamin $C$ deficiency. These results suggest that inflammation induces IL-22R $\alpha$ production in the cerebellum and hippocampus of Gulo (-/-) mice.

A

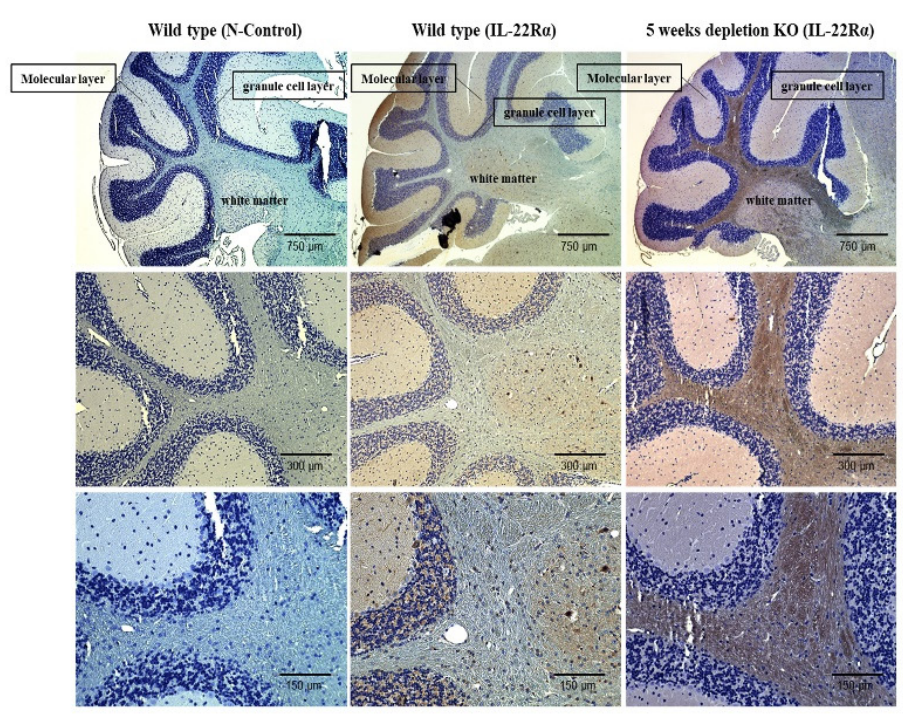

B

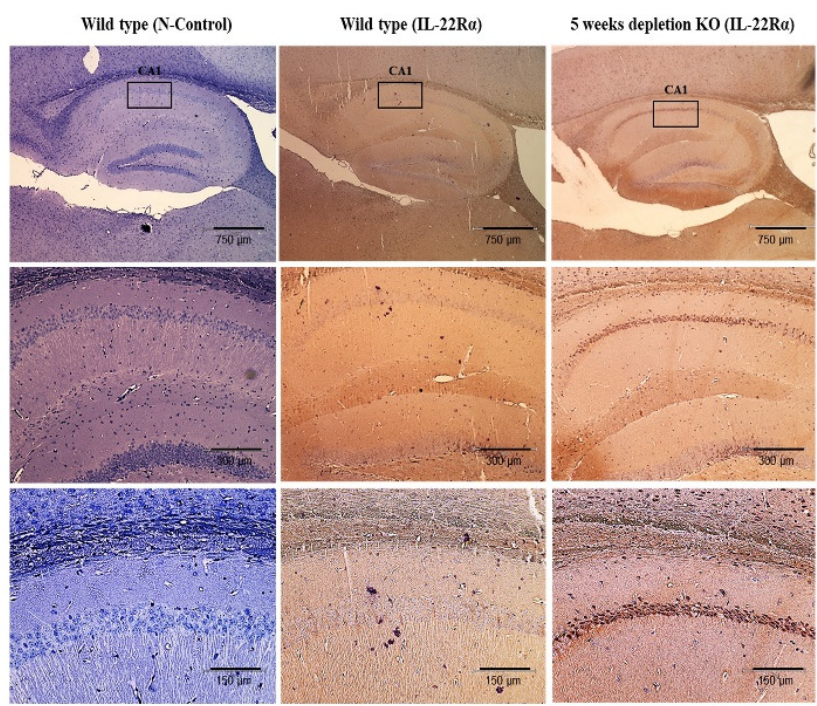

Figure 4. IL-22R $\alpha$ expression is increased in the Gulo (-/-) mouse brain upon inflammation. (A) Cerebellum. (B) Hippocampus, CA1 region is localized to the stratum pyramidal and apical dendritic arborization extending into the stratum radiatum. Immunohistochemical staining of the sagittal sections of the WT and 5 weeks Gulo (-/-) mouse brain and then paraffin-embedded tissues were sectioned with $4 \mu \mathrm{m}$ thickness and incubated with a primary antibody against IL-22R $\alpha$ and a biotinylated anti-rabbit antibody. Nuclei were counterstained with hematoxylin. Scale bar, $150 \mu \mathrm{m}$.

\subsection{Inflammatory Genes Are Upregulated by IL-22 Treatment of HT22 Cells}

Next, we used Affymetrix GeneChip ${ }^{\circledR}$ Mouse Gene 2.0 ST Arrays to examine the expression levels of inflammatory genes in HT22 cells following IL-22 treatment. Of the 109 genes analyzed (Figure 5A), 37 genes were upregulated following IL-22 treatment, and four of these genes were identified as inflammatory-related factors (Figure 5B). These genes included dynein, axonemal, heavy chain 7B (Dnah7b) [33], kallikrein 1-related peptidase b27 (Klk1b27) [34], immunoglobulin heavy variable 1-4 (Ighv1-4) [35,36], and glutathione peroxidase 2 (Gpx2) [37]. This section may be divided by subheadings. It should provide a concise and precise description of the experimental results, their interpretation, as well as the experimental conclusions that can be drawn. 


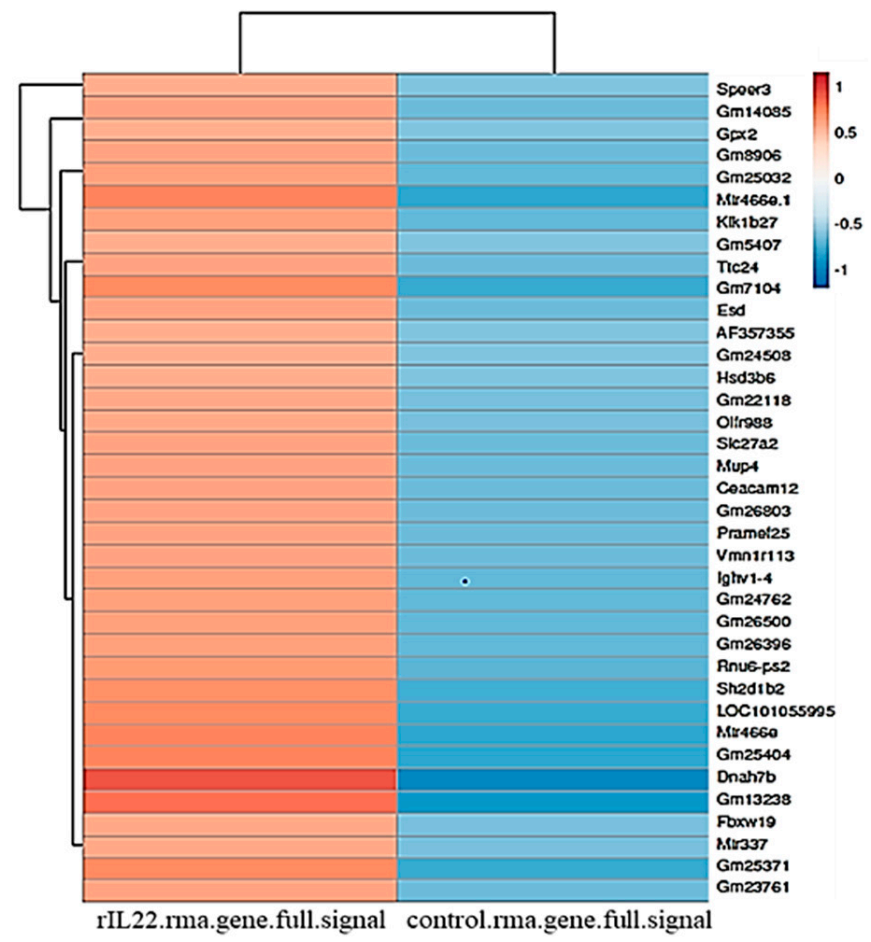

B

\begin{tabular}{|c|l|c|c|c|}
\hline Gene Symbol & \multicolumn{1}{c}{ Gene Description } & Absolute Fold Change & HT22 control.rma-gene-full-Signal & HT22 ril22.rma-gene-full-Signal \\
\hline Dnah7b & dynein, axonemal, heavy chain 7B & 3.078964002 & 1.750785 & 3.37323 \\
\hline Klk1b27 & kallikrein 1-related peptidase b27 & 2.208423717 & 2.797048 & 3.940065 \\
\hline Ighv1-4 & immunoglobulin heavy variable 1-4 & 2.178193316 & 3.031761 & 4.154893 \\
\hline Gpx2 & glutathione peroxidase 2 & 2.005418032 & 1.916107 & 2.92001 \\
\hline
\end{tabular}

Figure 5. Gene expression profiling of control versus IL-22-treated HT22 cells. (A) Heatmap displaying individual differentially expressed genes $(n=109)$ by microarray analysis using Affymetrix GeneChip ${ }^{\circledR}$ Mouse Gene 2.0 ST Arrays. (B) Subset of the inflammatory-related genes (Dnah7b, Klk1b27, Ighv1-4 and Gpx2) with large log2 fold-changes between IL-22-treated and control samples $(n=4)$.

\section{Discussion}

As a cytokine belonging to the IL-10 family, IL-22 is released from activated T cells and natural killer cells $[9,11]$. In addition, it has been reported recently that IL-22 is produced by activated macrophages [38-40]. Although IL-22 can have both pro-inflammatory and anti-inflammatory roles, its pro-inflammatory roles have been studied most extensively, and several studies have shown correlations between IL-22 production and inflammatory skin conditions, uveitis, Alzheimer's disease, and liver injury [7,11,12]. Nonetheless, IL-22 has an anti-inflammatory effect on inflammatory bowel diseases [41,42]. The cell surface-standing IL-22 receptor complex consists of the IL-22R $\alpha$ and IL-10R $\beta$ receptor chains [5]. IL-10R $\beta$ is expressed in all cells, including immune cells, whereas IL-22R $\alpha$ is reportedly expressed in non-hematopoietic cells of the skin, kidney, intestine, liver, and pancreas $[5,10,43]$. To our knowledge, there have been no investigations of IL-22R $\alpha$ expression in the brain; therefore, our current study examined IL-22 function and IL-22R $\alpha$ expression in the mouse brain.

We examined IL-22R $\alpha$ expression in the HT22 hippocampal neuronal cell line and the BV2 microglial cell line. The latter was selected because microglia protect the CNS by acting as the initial responders to infection [22,44,45]. Additionally, since IL-22R $\alpha$ is released from the liver, we used the Hepa1c1c7 mouse hepatoma cell line as a positive control. We found that IL-22R $\alpha$ was expressed at both the mRNA and protein level in BV2 and HT22 cells, 
and the levels of IL-22R $\alpha$ in both neuronal cell lines were similar to that in Hepa1c17 cells (Figure 1A-C). IL-10R $\beta$ expression was also confirmed in both cell lines. Previous studies have examined IL-22R $\alpha$ expression at the cellular level and in non-hematopoietic tissues such as the skin and pancreas $[9,11]$. In addition to its expression in mouse brain cell lines, we also identified IL-22R $\alpha$ expression in the hippocampus and cerebellum of C57BL/ 6 mice (Figure 1D). The hippocampus plays an important role in spatial memory and cognition, enabling information integration and transition from short-term memory to long-term memory $[25,35,46]$. In addition, the cerebellum is involved in motor control $[32,47,48]$. Therefore, defects of the hippocampus are related to Alzheimer's disease and those of the cerebellum are related to Parkinson's disease, both of which are inflammatory brain diseases $[25,49]$. With this in mind, we examined the effect of vitamin C deficiency-induced brain inflammation on IL-22R $\alpha$ expression in mice. The brain and cerebrospinal fluid have high concentrations of vitamin $\mathrm{C}$, and oxidative stress in relation to the therapeutic function of vitamin $C$ has been implicated to develop neurodegenerative diseases [32]. In our current study, a 5-week deficiency of vitamin $C$ created an inflammatory environment in mice and upregulated expression of IL-22R $\alpha$ in the cerebellum white matter region, as well as the CA1 region of the hippocampus. Overall, these findings demonstrate that IL-22R $\alpha$ is expressed in the brain and is upregulated during inflammatory responses.

It is known that IL-22 shares its function with IL-17 in terms of epithelial protection and regeneration of skin, lung, and gastrointestinal tract $[9,14]$. It was recently reported by Zhao, N. et al. that the modulation of Th17/Treg imbalance in CSE-induced experimental COPD is achieved by the inhibition of IL-22-dependent JAK/STAT3 pathway [50]. While IL-17 shows its function as a pro-inflammatory cytokine, IL-22 has roles of both an antiinflammatory cytokine as well as pro-inflammatory cytokine. Even though IL-22 plays as an anti-inflammatory cytokine in IBD and sepsis-induced liver injury [3], its role in the inflamed-brain is still not elucidated. That is why we examined the inflammatory role of IL-22 on brain inflammation in this study. In case of inflammation in brain, it seems that Th17/Treg imbalance is not directly involved in the development and pathogenesis of inflammation in brain, since $\mathrm{T}$ cell is not resided in the brain. However, it is worthy to examine the expression of IL-17R, like the expression of IL-22R $\alpha$, on neuronal cells, especially cells in animal models with Parkinson's disease and Alzheimer's disease.

As IL-22 is involved in the induction of inflammatory responses in other tissues, we investigated its effects on the production of inflammatory cytokines [41,51], and found that treatment of BV2 and HT22 cells with IL-22 increased the levels of TNF- $\alpha$ (Figure 2A) and IL-6 (Figure S1). Previous studies have shown that binding of IL-22 to IL-22R $\alpha$ induces the JAK1, STAT3, and STAT5 pathways, as well as the MAP kinase pathways $[17,52,53]$. In line with these reports, we found that pretreatment of BV2 cells with SP600125 (a specific inhibitor of JNK) and pretreatment of HT22 cells with S3I-201 (a specific inhibitor of STAT3) attenuated the IL-22-induced increase in TNF- $\alpha$ (Figure 3A,B). At the same time, the phosphorylation of JNK (Figure 3C) and phosphorylation of STAT3 (Figure 3D) were increased in IL-22-treated BV2 and HT22 cells, respectively. Overall, these findings suggest that IL-22 induces pro-inflammatory cytokine production in mouse brain cells and that the JNK pathway is involved in IL-22-induced TNF- $\alpha$ expression in BV2 cells, whereas the STAT3 pathway is involved in this response in HT22 cells. Even though the signaling pathways for TNF- $\alpha$ production in both cell lines are different, our results suggest that IL-22 might induce inflammation in the brain through TNF- $\alpha$ production. Considering the pathogenic role of STAT3 in the several kinds of inflammatory diseases, it also implies that the substances, which can suppress STAT3 activation, could be used more effectively for the regulation of IL-22-induced inflammation in the brain.

Inflammatory prostaglandin signaling plays a role in the preclinical development of neurodegenerative diseases $[29,30,54]$. COX-2, the inducible form of the COX enzyme involved in prostaglandin synthesis, is rarely expressed in steady state but is induced rapidly following stimulation by a mitogen, cytokine, or lipopolysaccharide $[28,31,55]$. Here, we found that COX-2 expression was increased following treatment of BV2 and HT22 cells 
with IL-22, and there was a time difference between the responses of the BV2 and HT22 cell lines at the transcriptional (Figure 2B) and translational levels (Figure 2C). In line with the fact that overexpression of COX-2 eventually leads to increased prostaglandin formation, we also found that PGE2 production was increased by treatment of BV2 and HT22 cells with IL-22 (Figure 2D). In addition, IL-22-induced PGE2 production was decreased in cells treated with NS-398, a COX-2 specific inhibitor (Figure 2E). Although microglia function to protect the body, over-activation can result in the production of IL- 6 , IL- $1 \beta$, TNF- $\alpha$, and other inflammatory cytokines, resulting in neuronal death and chronic inflammation, the major causes of degenerative brain disease [56,57].

Microarray gene expression profiling enables investigation of genome-wide changes in gene expression and provides an unbiased approach for identifying genes that are regulated under pathological conditions. Therefore, we used microarrays to identify genes that are differentially expressed in HT22 cells following treatment with IL-22. We found that the expression levels of the inflammatory genes Dnah7b, Klkb27, Ighv1-4, and Gpx2 were upregulated following IL-22 treatment (Figure 5). Dnah7b promotes androgen receptor activity and is expressed at high levels in primary tumors [58]. Kallikrein 1-related peptidase b27 (Klk1b27) is important for neuronal development and plasticity [59]. Immunoglobulinheavy variable 1-4 (Ighv1-4) accounts for 85\% of follicular lymphoma cases [60]. Glutathione peroxidase 2 (Gpx2) catalyzes the reduction of $\mathrm{H} 2 \mathrm{O} 2$ by glutathione [34,61].

Inflammation in the brain contributes to the development of Alzheimer's and Parkinson's diseases, and pathological studies have shown that increased levels of COX-2, PGE2, IL-6, and TNF- $\alpha$ play a role in these degenerative brain diseases [62-64]. Notably, the levels of these factors were increased in IL-22-treated mouse neuronal cells. It is highly likely that these effects rely on the interaction of IL-22 with IL-22R $\alpha$. For this reason, experiments using animal models to examine the roles of IL-22 and IL-22R $\alpha$ in the development and progression of Alzheimer's and Parkinson's diseases are warranted. We also found that treatment of BV2 and HT22 cells with IL-23 increased expression of IL-22R $\alpha$ (data not shown: Material not intended for publication). Thus, regulation of IL-22R $\alpha$ expression through the regulation of IL-23 may be a starting point for controlling inflammation in the brain and the consequent development of degenerative brain diseases such as Alzheimer's and Parkinson's. If IL-22R $\alpha$ is already expressed at high levels, it may be possible to block its function using a neutralizing Ab or soluble IL-22 binding protein. Based on our unpublished data regarding the expression of IL-22 binding protein (BP), it was expressed only in BV2, but not in HT22 (Figure S2). Considering several reports that microglia have a role in the protection of neurons, it seems that IL-22BP has a protective role in IL-22induced damage of neuron. Therefore, the additional experiment using animal models with inflammation in the brain should be needed.

This study was performed using cell lines and an animal model; follow-up studies using human brain tissue donated to the brain tissue bank are required to confirm our findings. Macrophages present in the brain and non-neuronal cells that are differentiated from monocytes and scattered in the CNS play an important role in brain inflammation. These large-sized cells cannot pass the blood-brain barrier and are difficult to examine using nanotechnology. Binding of IL-22 to IL-22R $\alpha$ on the surface of BV2 and HT22 cells might play an important role in the proliferation of these cells and the production of inflammatory mediators.

\section{Materials and Methods}

\subsection{Cell Lines and Culture Conditions}

The BV2 murine microglial cell line, HT22 murine hippocampal neuronal cell line, and Hepa1c1c7 murine hepatoma cell line were maintained in DMEM (HyClone, Queensland, Australia) supplemented with 10\% heat-inactivated fetal bovine serum (HyClone, Queensland, Australia) and antibiotics (100 U/mL penicillin and $100 \mu \mathrm{g} / \mathrm{mL}$ streptomycin; Welgene, Namcheon-myeon, South Korea) at $37^{\circ} \mathrm{C}$ in a humidified atmosphere containing 
5\% CO2. The HT22 cell line was kindly provided by professor Inhee Mook-Jung (Seoul National University College of Medicine).

\subsection{Animals}

As described in our previous study [32], Gulo (-/-) mice (C57BL/6 background) lacking vitamin $C$ supplementation for 5 weeks were used as a model of spontaneous brain inflammation. Gulo (-/-) mice were maintained in specific pathogen-free conditions in the animal facility at Seoul National University College of Medicine. The animal protocol was reviewed and approved by the Ethics Committee of Seoul National University (IACUC: SNU-200319-2).

\subsection{Immunohistochemistry}

Gulo (-/-) mice without vitamin C supplementation for 5 weeks were sacrificed and perfused with $4 \%$ paraformaldehyde (PFA). The brains were removed and post-fixed in $4 \%$ PFA at $4{ }^{\circ} \mathrm{C}$ overnight. Subsequently, the brains were transferred to $15 \%$ sucrose, placed at room temperature for $6 \mathrm{~h}$, and then stored in $30 \%$ sucrose at $4{ }^{\circ} \mathrm{C}$ overnight. Fixed tissues were embedded in paraffin and sectioned with $4 \mu \mathrm{m}$ thickness. After de-paraffinization and hydration, the antigen epitope was retrieved by heating with $0.1 \mathrm{M}$ citrate buffer ( $\mathrm{pH}$ 6.0) in a microwave. Subsequently, endogenous peroxidase was blocked with $\mathrm{H} 2 \mathrm{O} 2$, and non-specific signals were blocked by incubating the sections with blocking solution (Vector Laboratories, Burlingame, CA, USA) containing $5 \%$ goat serum for $1 \mathrm{~h}$ at room temperature. To examine the expression level of IL-22R $\alpha$, tissue sections were incubated with a specific primary antibody (1:150; Abcam, Cambridge, UK) in a humidified chamber at $4{ }^{\circ} \mathrm{C}$ overnight. Subsequently, the sections were incubated with biotinylated goat anti-rat immunoglobulin as a secondary (1:250; Vector Laboratories) for $1 \mathrm{~h}$ at room temperature. $\mathrm{ABC}$ solution (Vector Laboratories) was loaded onto the sections for $30 \mathrm{~min}$ and a DAB kit (Vector Laboratories) was used for chromogenic detection. After counterstaining with hematoxylin, dehydration and clearing, tissue sections were mounted onto glass slides (Life Technologies, Frederick, MD, USA). An Olympus AX-70 microscope equipped with a motorized stage (Olympus, Melville, NY, USA) was used for visualization and data were analyzed using MCID 6.0 Elite Imaging Software (GE Healthcare, Piscataway, NJ, USA).

\subsection{Flow Cytometry}

BV2 and HT22 cells were resuspended in fluorescence-activated cell sorting (FACS) buffer containing $0.5 \%$ bovine serum albumin and blocked at $4{ }^{\circ} \mathrm{C}$ for 10 min with FcR blocking reagent (Miltenyi Biotec $\mathrm{GmbH}$, Bergisch Gladbach, Germany). To examine the expression level of IL-22R $\alpha$, cells were incubated with a rabbit-derived polyclonal antiIL-22R $\alpha \mathrm{Ab}\left(2.5 \mu \mathrm{g} / 10^{6}\right.$ cells; Abcam) at $4{ }^{\circ} \mathrm{C}$ for $30 \mathrm{~min}$. After washing the cells three times with FACS buffer and centrifuging at $1500 \mathrm{rpm}$ ( $3 \mathrm{~min}$ each), the cells were stained with FITC-conjugated mouse-derived anti-rabbit IgG (1:400; Santa Cruz Bio-technology, Santa Cruz, CA, USA) on ice for $30 \mathrm{~min}$. Subsequently, the cells were washed twice with FACS buffer (3 min each) and analyzed via Attune NxT Flow Cytometry (Thermo Scientific, Wilmington, DE, USA). FlowJo software (Tree Star, Ash-land, OR, USA) was used for data analysis.

\subsection{Reverse Transcription-Polymerase Chain Reaction (RT-PCR)}

Cells were pretreated with a specific inhibitor of JNK (SP600125, $20 \mu \mathrm{M}$; Sigma, St. Louis, MO, USA) or STAT3 (S3I-201, $50 \mu \mathrm{M}$; Sigma) for $1 \mathrm{~h}$. After washing with PBS, the cells were treated with IL-22 $(20 \mathrm{ng} / \mathrm{mL})$ and cultured for a further $48 \mathrm{~h}$. Total cellular RNA was extracted from BV2 and HT22 cells $\left(1 \times 10^{6}\right)$ using TRIzol reagent (Invitrogen, Carlsbad, CA, USA). Reverse transcription was performed using $1 \mu \mathrm{g}$ total RNA in a firststrand complementary DNA synthesis reaction with AMV Reverse Transcriptase (Promega, Madison, WI, USA). The sequences of the primers used for RT-PCR were as follows: $5^{\prime}$-CTG CAA CCT GAC TAT GGA GA-3' (forward) and 5'-TTC ACT CGG CAC ACG TAG GG-3' 
(reverse) for IL-22R $\alpha$ (425 bp); 5'-AAG CAG AGT CCT GAA GAC AA-3' (forward) and 5'-AGA TCA CTG TGA TCC TG-3' (reverse) for IL-10R $\beta$ (310 bp); 5'-ACA CAC TCT ATC ACT GGC ACC-3' (forward) and 5'-TTC AGG GAG AAG CGT TTG C -3' (reverse) for COX-2 (274 bp); 5'-TAC AGG CTT GTC ACT CGA ATT-3' (forward) and 5'-ATG AGC ACA GAA AGC ATG ATC-3' (reverse) for TNF- $\alpha$ (263 bp); and 5'-GAG AGT GGT GCC AGT CTA GT-3' (forward) and 5'-GCC ACA CTC CAC AAT CA-3' (reverse) for $\beta$-actin (207 bp). The PCR amplification conditions were as follows: 35 cycles of $94{ }^{\circ} \mathrm{C}$ for $15 \mathrm{~s}, 57^{\circ} \mathrm{C}$ for $45 \mathrm{~s}$, and $72{ }^{\circ} \mathrm{C}$ for $1 \mathrm{~min}(\mathrm{IL}-22 \mathrm{R} \alpha) ; 30$ cycles of $94{ }^{\circ} \mathrm{C}$ for $15 \mathrm{~s}, 58{ }^{\circ} \mathrm{C}$ for $45 \mathrm{~s}$, and $72{ }^{\circ} \mathrm{C}$ for $1 \mathrm{~min}$ (IL-10R $\beta$ ); 35 cycles of $94^{\circ} \mathrm{C}$ for $15 \mathrm{~s}, 55^{\circ} \mathrm{C}$ for $45 \mathrm{~s}$, and $72{ }^{\circ} \mathrm{C}$ for $1 \mathrm{~min}(\mathrm{COX}-2)$; 40 cycles of $94{ }^{\circ} \mathrm{C}$ for $15 \mathrm{~s}, 57^{\circ} \mathrm{C}$ for $45 \mathrm{~s}$, and $72{ }^{\circ} \mathrm{C}$ for $1 \mathrm{~min}(\mathrm{TNF}-\alpha)$; and 35 cycles of $94{ }^{\circ} \mathrm{C}$ for $15 \mathrm{~s}, 58.1^{\circ} \mathrm{C}$ for $45 \mathrm{~s}$, and $72{ }^{\circ} \mathrm{C}$ for $1 \mathrm{~min}$ ( $\beta$-actin). PCR products were separated by electrophoresis on a $1.5 \%$ agarose gel and visualized by staining with Red Safe (Intron Biotechnology, Seong-nam, Korea). The density of each band was analyzed using ImageJ software (NIH, Bethesda, MD, USA).

\subsection{Western Blotting}

BV2 and HT22 cells $\left(1 \times 10^{6}\right)$ were lysed, and proteins were extracted using lysis buffer containing $50 \mathrm{mM}$ Tris-HCL (pH 7.4), 1\% NP-40, 0.25\% sodium deoxycholate, $150 \mathrm{mM}$ $\mathrm{NaCl}, 1 \mathrm{mM}$ EDTA, and protease inhibitor cocktails. The protein concentration was measured using a BCA assay. Equal amounts of protein $(30 \mu \mathrm{g} / \mathrm{sample})$ were dissolved in a $10 \%$ polyacrylamide-SDS gel at $100 \mathrm{~V}$ for $2 \mathrm{~h}$ and transferred onto a nitrocellulose membrane. Blocking was performed at room temperature for $1 \mathrm{~h}$ with $5 \%$ non-fat milk in PBS containing $0.1 \%$ Tween 20 (PBST). To determine the expression levels of IL-22R $\alpha$ and IL-10R $\beta$, the blocked membrane was incubated with an anti-IL-22R $\alpha$ Ab (1:5000; Abcam), anti-IL-10R $\beta$ Ab (1:5000; Santa Cruz Biotechnology), anti-phospho-c-Jun Ab (1:1000; Cell Signaling Technology, Boston, MA, USA), anti-c-Jun Ab (1:1000; Cell Signaling Technology), anti-phospho-STAT3 Ab (1:1000; Cell Signaling Technology), anti-STAT3 Ab (1:1000; Cell Signaling Technology), or anti- $\beta$-actin Ab (1:5000; Santa Cruz Biotechnology) at $4{ }^{\circ} \mathrm{C}$ overnight. After washing three times (5 min each) with $0.1 \%$ PBST, the membrane was incubated for $1 \mathrm{~h}$ at room temperature with horseradish peroxidase (HRP)-conjugated anti-rabbit IgG (1:10,000; Cell Signaling Technology) to detect IL-22R $\alpha$, c-Jun, or phospho-cJun, or with HRP-conjugated anti-mouse IgG (1:10,000; Cell Signaling) to detect IL-10R $\beta$, $\beta$-actin, phopsho-STAT3, and STAT3. Subsequently, the membrane was washed three times (5 min each), and the immunoreactive proteins were visualized with an electrochemical luminescence detection system (Thermo Scientific). The densities of the bands were analyzed using ImageJ software (NIH) and normalized to that of $\beta$-actin.

\subsection{Enzyme-Linked Immunosorbent Assay (ELISA)}

BV2 cells $\left(1 \times 10^{5}\right)$ or HT22 cells $\left(2 \times 10^{5}\right)$ were seeded into 6-well plates with or without recombinant (r)IL-22 (R\&D Systems, Minneapolis, MN, USA) and/or NS-398 (40 $\mathrm{MM}$; Sigma), and were allowed to grow to confluence for 24 or $48 \mathrm{~h}$. Subsequently, the concentrations of IL-6, TNF- $\alpha$ (BioLegend, San Diego, CA, USA), and PGE2 (R\&D Systems) in the supernatants were measured by ELISA, according to the manufacturers' instructions. Relative absorbance was measured at $450 \mathrm{~nm}$ using a SpectraMax iD3 microplate reader (Molecular Devices, San Jose, CA, USA).

\subsection{Gene Expression Profiling}

Changes in gene expression profiles in HT22 cells treated with rIL-22 $(20 \mathrm{ng} / \mathrm{mL})$ were determined by microarray analysis using Affymetrix GeneChip ${ }^{\circledR}$ Mouse Gene 2.0 ST Arrays. Total cellular RNA was extracted from $1 \times 10^{6}$ cells using TRIzol reagent (Invitrogen). RNA quality was assessed using an Agilent 2100 bioanalyzer and the RNA 6000 Nano Chip (Agilent Technologies, Santa Clara, CA, USA), and quantity was determined using a Nanodrop-1000 spectrophotometer (Thermo Scientific). For microarray analyses, $300 \mathrm{ng}$ RNA was used as input, as recommended by the Affymetrix protocol. The expression 
intensity data were extracted from the scanned images using Affymetrix Command Console software (version 1.1). After confirming that the data were normalized properly, genes that showed more than a 2 -fold difference between the average signal values of the control and treatment groups were selected.

\subsection{Statistical Analysis}

Data are presented as the mean \pm SD. Unpaired $t$-tests were used to compare two groups. Statistical analysis was carried out using GraphPad Software Prism version 6.01 (GraphPad Software, Le Jolla, CA, USA).

\section{Conclusions}

Our findings indicate that IL-22R $\alpha$ is spontaneously expressed in brain cells, especially microglia and hippocampal neurons, and is involved in the development of inflammatory responses following binding of its ligand IL-22.

Supplementary Materials: The following are available online at https:/ /www.mdpi.com/article/ $10.3390 /$ ijms23020757/s1.

Author Contributions: Conceptualization, J.S.K.; methodology, Y.K. and J.S.K.; formal analysis, D.L. and Y.K.; investigation, D.L., H.J., C.G., Y.J., N.C. and S.B.; resources, Y.K. and J.S.K.; data curation, Y.K. and J.S.K.; writing-original draft preparation, D.L., Y.K. and J.S.K.; writing-review and editing, D.L., D.K., Y.K. and J.S.K.; visualization, D.L.; project administration, J.S.K.; funding acquisition, Y.K. and J.S.K. All authors have read and agreed to the published version of the manuscript.

Funding: This study was funded by the NRF of Korea (No.: 2017R1A2B2010948, 2017R1A6A3A11032576, 2020R1C1C1009334).

Institutional Review Board Statement: Not applicable.

Informed Consent Statement: Not applicable.

Data Availability Statement: All datasets generated for this study are included in the article or Supplementary File.

Conflicts of Interest: The authors declare that the research was conducted in the absence of any commercial or financial relationships that could be construed as a potential conflict of interest.

\section{References}

1. Chen, E.; Cen, Y.; Lu, D.; Luo, W.; Jiang, H. IL-22 inactivates hepatic stellate cells via downregulation of the TGF-beta1/Notch signaling pathway. Mol. Med. Rep. 2018, 17, 5449-5453.

2. Mihi, B.; Gong, Q.; Nolan, L.S.; Gale, S.E.; Goree, M.; Hu, E.; Lanik, W.E.; Rimer, J.M.; Liu, V.; Parks, O.B.; et al. Interleukin-22 signaling attenuates necrotizing enterocolitis by promoting epithelial cell regeneration. Cell Rep. Med. 2021, 2, 100320. [CrossRef] [PubMed]

3. Sakemi, R.; Mitsuyama, K.; Morita, M.; Yoshioka, S.; Kuwaki, K.; Tokuyasu, H.; Fukunaga, S.; Mori, A.; Araki, T.; Yoshimura, T.; et al. Altered serum profile of the interleukin-22 system in inflammatory bowel disease. Cytokine 2020, $136,155264$. [CrossRef]

4. Kong, X.; Feng, D.; Wang, H.; Hong, F.; Bertola, A.; Wang, F.-S.; Gao, B. Interleukin-22 induces hepatic stellate cell senescence and restricts liver fibrosis in mice. Hepatology 2012, 56, 1150-1159. [CrossRef] [PubMed]

5. Mossner, S.; Kuchner, M.; Modares, N.F.; Knebel, B.; Al-Hasani, H.; Floss, D.M.; Scheller, J. Synthetic interleukin 22 (IL-22) signaling reveals biological activity of homodimeric IL-10 receptor 2 and functional cross-talk with the IL-6 receptor gp130. J. Biol. Chem. 2020, 295, 12378-12397. [CrossRef]

6. Akil, H.; Abbaci, A.; Lalloué, F.; Bessette, B.; Costes, L.M.; Domballe, L.; Lecron, J.C.; Bernard, F.X.; Morel, F.; Tapon, K.; et al. IL22/IL-22R pathway induces cell survival in human glioblastoma cells. PLoS ONE 2015, 10, e0119872. [CrossRef] [PubMed]

7. Keir, M.E.; Yi, T.; Lu, T.T.; Ghilardi, N. The role of IL-22 in intestinal health and disease. J. Exp. Med. 2020, 217 , e20192195. [CrossRef] [PubMed]

8. Stallhofer, J.; Friedrich, M.; Konrad-Zerna, A.; Wetzke, M.; Lohse, P.; Glas, J.; Tillack-Schreiber, C.; Schnitzler, F.; Beigel, F.; Brand, S. Lipocalin-2 Is a Disease Activity Marker in Inflammatory Bowel Disease Regulated by IL-17A, IL-22, and TNF- $\alpha$ and Modulated by IL23R Genotype Status. Inflamm. Bowel Dis. 2015, 21, 2327-2340. [CrossRef] 
9. Nograles, K.E.; Zaba, L.C.; Shemer, A.; Fuentes-Duculan, J.; Cardinale, I.; Kikuchi, T.; Guttman-Yassky, E.; Bergman, R.; Krueger, J.; Yassky, E.G.; et al. IL-22-producing “T22" T cells account for upregulated IL-22 in atopic dermatitis despite reduced IL-17-producing TH17 T cells. J. Allergy Clin. Immunol. 2009, 123, 1244.e2-1252 e2. [CrossRef]

10. Liang, S.C.; Nickerson-Nutter, C.; Pittman, D.D.; Carrier, Y.; Goodwin, D.G.; Shields, K.M.; Lambert, A.-J.; Schelling, S.H.; Medley, Q.G.; Ma, H.-L.; et al. IL-22 Induces an Acute-Phase Response. J. Immunol. 2010, 185, 5531-5538. [CrossRef]

11. Trifari, S.; Spits, H. IL-22-producing CD4+ T cells: Middle-men between the immune system and its environment. Eur. J. Immunol. 2010, 40, 2369-2371. [CrossRef]

12. Das, S.; Croix, C.S.; Good, M.; Chen, J.; Zhao, J.; Hu, S.; Ross, M.; Myerburg, M.M.; Pilewski, J.M.; Williams, J.; et al. Interleukin-22 Inhibits Respiratory Syncytial Virus Production by Blocking Virus-Mediated Subversion of Cellular Autophagy. iScience 2020, 23, 101256. [CrossRef]

13. Patnaude, L.; Mayo, M.; Mario, R.; Wu, X.; Knight, H.; Creamer, K.; Wilson, S.; Pivorunas, V.; Karman, J.; Phillips, L.; et al. Mechanisms and regulation of IL-22-mediated intestinal epithelial homeostasis and repair. Life Sci. 2021, 271, 119195. [CrossRef] [PubMed]

14. Nikoopour, E.; Bellemore, S.M.; Singh, B. IL-22, cell regeneration and autoimmunity. Cytokine 2015, 74, 35-42. [CrossRef] [PubMed]

15. Pickert, G.; Neufert, C.; Leppkes, M.; Zheng, Y.; Wittkopf, N.; Warntjen, M.; Lehr, H.-A.; Hirth, S.; Weigmann, B.; Wirtz, S.; et al STAT3 links IL-22 signaling in intestinal epithelial cells to mucosal wound healing. J. Exp. Med. 2009, 206, 1465-1472. [CrossRef] [PubMed]

16. Mitra, A.; Raychaudhuri, S.K.; Raychaudhuri, S.P. IL-22 induced cell proliferation is regulated by PI3K/Akt/mTOR signaling cascade. Cytokine 2012, 60, 38-42. [CrossRef]

17. Yu, L.Z.; Wang, H.Y.; Yang, S.P.; Yuan, Z.P.; Xu, F.Y.; Sun, C.; Shi, R.H. Expression of interleukin-22/STAT3 signaling pathway in ulcerative colitis and related carcinogenesis. World J. Gastroenterol. 2013, 19, 2638-2649. [CrossRef]

18. Park, G.-H.; Noh, H.; Shao, Z.; Ni, P.; Qin, Y.; Liu, D.; Beaudreault, C.P.; Park, J.S.; Abani, C.P.; Park, J.M.; et al. Activated microglia cause metabolic disruptions in developmental cortical interneurons that persist in interneurons from individuals with schizophrenia. Nat. Neurosci. 2020, 23, 1352-1364. [CrossRef]

19. Rodríguez-Gómez, J.A.; Kavanagh, E.; Engskog-Vlachos, P.; Engskog, M.K.; Herrera, A.J.; Espinosa-Oliva, A.M.; Joseph, B.; Hajji, N.; Venero, J.L.; Burguillos, M.A. Microglia: Agents of the CNS Pro-Inflammatory Response. Cells 2020, 9, 1717. [CrossRef] [PubMed]

20. Wang, P.L.; Yim, A.K.Y.; Kim, K.-W.; Avey, D.; Czepielewski, R.S.; Colonna, M.; Milbrandt, J.; Randolph, G.J. Peripheral nerve resident macrophages share tissue-specific programming and features of activated microglia. Nat. Commun. 2020, 11, 2552. [CrossRef]

21. Pinto, B.; Morelli, G.; Rastogi, M.; Savardi, A.; Fumagalli, A.; Petretto, A.; Bartolucci, M.; Varea, E.; Catelani, T.; Contestabile, A.; et al. Rescuing Over-activated Microglia Restores Cognitive Performance in Juvenile Animals of the Dp(16) Mouse Model of Down Syndrome. Neuron 2020, 108, 887.e12-904.e12. [CrossRef] [PubMed]

22. Stephenson, J.; Nutma, E.; Van Der Valk, P.; Amor, S. Inflammation in CNS neurodegenerative diseases. Immunology 2018, 154, 204-219. [CrossRef] [PubMed]

23. Urban, S.L.; Jensen, I.J.; Shan, Q.; Pewe, L.L.; Xue, H.-H.; Badovinac, V.; Harty, J.T. Peripherally induced brain tissue-resident memory CD8+ T cells mediate protection against CNS infection. Nat. Immunol. 2020, 21, 1-12. [CrossRef] [PubMed]

24. Seidler, R.D.; Bernard, J.A.; Burutolu, T.B.; Fling, B.W.; Gordon, M.T.; Gwin, J.T.; Kwak, Y.; Lipps, D.B. Motor control and aging: Links to age-related brain structural, functional, and biochemical effects. Neurosci. Biobehav. Rev. 2010, 34, 721-733. [CrossRef] [PubMed]

25. Jung, J.H.; Kim, B.H.; Chung, S.J.; Yoo, H.S.; Lee, Y.H.; Baik, K.; Lee, P.H. Motor Cerebellar Connectivity and Future Development of Freezing of Gait in De Novo Parkinson's Disease. Mov. Disord. 2020, 35, 2240-2249. [CrossRef]

26. Kosuge, Y.; Nango, H.; Kasai, H.; Yanagi, T.; Mawatari, T.; Nishiyama, K.; Miyagishi, H.; Ishige, K.; Ito, Y. Generation of Cellular Reactive Oxygen Species by Activation of the EP2 Receptor Contributes to Prostaglandin E2-Induced Cytotoxicity in Motor Neuron-Like NSC-34 Cells. Oxidative Med. Cell. Longev. 2020, 2020, 1-14. [CrossRef]

27. Fransen, N.L.; Hsiao, C.-C.; Van Der Poel, M.; Engelenburg, H.J.; Verdaasdonk, K.; Vincenten, M.C.J.; Remmerswaal, E.B.M.; Kuhlmann, T.; Mason, M.R.J.; Hamann, J.; et al. Tissue-resident memory T cells invade the brain parenchyma in multiple sclerosis white matter lesions. Brain 2020, 143, 1714-1730. [CrossRef]

28. Grzanna, M.W.; Au, R.Y.; Au, A.Y.; Rashmir, A.M.; Frondoza, C.G. Avocado/Soybean Unsaponifiables, Glucosamine and Chondroitin Sulfate Combination Inhibits Proinflammatory COX-2 Expression and Prostaglandin E2 Production in TendonDerived Cells. J. Med. Food 2020, 23, 139-146. [CrossRef]

29. Zhu, X.; Yao, Y.; Yang, J.; Zhengxie, J.; Li, X.; Hu, S.; Zhang, A.; Dong, J.; Zhang, C.; Gan, G. COX-2-PGE2 signaling pathway contributes to hippocampal neuronal injury and cognitive impairment in PTZ-kindled epilepsy mice. Int. Immunopharmacol. 2020 87, 106801. [CrossRef]

30. Yu, Y.; Jiang, J. COX-2/PGE2 axis regulates hippocampal BDNF/TrkB signaling via EP2 receptor after prolonged seizures Epilepsia Open. 2020, 5, 418-431. [CrossRef]

31. Alvarez, A.M.; DeOcesano-Pereira, C.; Teixeira, C.; Moreira, V. IL-1beta and TNF-alpha Modulation of Proliferated and Committed Myoblasts: IL-6 and COX-2-Derived Prostaglandins as Key Actors in the Mechanisms Involved. Cells 2020, 9, 2005. [CrossRef] 
32. Kim, H.; Kim, Y.; Bae, S.; Lim, S.H.; Jang, M.; Choi, J.; Lee, W.J. Vitamin C Deficiency Causes Severe Defects in the Development of the Neonatal Cerebellum and in the Motor Behaviors of Gulo(-/-) Mice. Antioxidants Redox Signal. 2015, 23, 1270-1283. [CrossRef]

33. Lee, H.K.; Widmayer, S.J.; Huang, M.-N.; Aylor, D.L.; Marchuk, D.A. Novel Neuroprotective Loci Modulating Ischemic Stroke Volume in Wild-Derived Inbred Mouse Strains. Genetics 2019, 213, 1079-1092. [CrossRef]

34. McConaha, M.; Eckstrum, K.; An, J.; Steinle, J.J.; Bany, B.M. Microarray assessment of the influence of the conceptus on gene expression in the mouse uterus during decidualization. Reproduction 2011, 141, 511-527. [CrossRef]

35. Dubey, S.; Heinen, S.; Krantic, S.; McLaurin, J.; Branch, D.R.; Hynynen, K.; Aubert, I. Clinically approved IVIg delivered to the hippocampus with focused ultrasound promotes neurogenesis in a model of Alzheimer's disease. Proc. Natl. Acad. Sci. USA 2020, 117, 32691-32700. [CrossRef] [PubMed]

36. Buckley, N.A.; Baskaya, M.K.; Darsie, M.E. Intravenous Immunoglobulin (IVIG) in Severe Heparin-Induced Thrombocytopenia (HIT) in a Traumatic Brain Injury (TBI) Patient with Cerebral Venous Sinus Thrombosis (CVST). Neurocrit. Care 2020, 34, 1103-1107. [CrossRef]

37. Brigelius-Flohé, R.; Kipp, A. Physiological functions of GPx2 and its role in inflammation-triggered carcinogenesis. Ann. N. Y. Acad. Sci. 2012, 1259, 19-25. [CrossRef]

38. Bennett, F.; Bennett, M.; Yaqoob, F.; Mulinyawe, S.B.; Grant, G.A.; Gephart, M.H.; Plowey, E.D.; Barres, B.A. A Combination of Ontogeny and CNS Environment Establishes Microglial Identity. Neuron 2018, 98, 1170-1183.e8. [CrossRef] [PubMed]

39. Gutmann, D.H.; Kettenmann, H. Microglia/Brain Macrophages as Central Drivers of Brain Tumor Pathobiology. Neuron 2019, 104, 442-449. [CrossRef]

40. Walker, D.G.; Tang, T.M.; Mendsaikhan, A.; Tooyama, I.; Serrano, G.E.; Sue, L.I.; Beach, T.G.; Lue, L.-F. Patterns of Expression of Purinergic Receptor P2RY12, a Putative Marker for Non-Activated Microglia, in Aged and Alzheimer's Disease Brains. Int. J. Mol. Sci. 2020, 21, 678. [CrossRef] [PubMed]

41. Leppkes, M.; Neurath, M.F. Cytokines in inflammatory bowel diseases-Update 2020. Pharmacol. Res. 2020, 158, 104835. [CrossRef] [PubMed]

42. Li, Y.-Y.; Wang, X.-J.; Su, Y.-L.; Wang, Q.; Huang, S.-W.; Pan, Z.-F.; Chen, Y.-P.; Liang, J.-J.; Zhang, M.-L.; Xie, X.-Q.; et al. Baicalein ameliorates ulcerative colitis by improving intestinal epithelial barrier via AhR/IL-22 pathway in ILC3s. Acta Pharmacol. Sin. 2021, 1-13. [CrossRef] [PubMed]

43. Wang, J.; Gao, S.; Zhang, J.; Li, C.; Li, H.; Lin, J. Interleukin-22 attenuates allergic airway inflammation in ovalbumin-induced asthma mouse model. BMC Pulm. Med. 2021, 21, 1-10. [CrossRef] [PubMed]

44. Bar, M. The proactive brain: Memory for predictions. Philos. Trans. R. Soc. B Biol. Sci. 2009, 364, 1235-1243. [CrossRef] [PubMed]

45. Masuda, T.; Amann, L.; Sankowski, R.; Staszewski, O.; Lenz, M.; Snaidero, N.; Prinz, M. Novel Hexb-based tools for studying microglia in the CNS. Nat. Immunol. 2020, 21, 802-815. [CrossRef]

46. Ressler, R.L.; Goode, T.D.; Kim, S.; Ramanathan, K.R.; Maren, S. Covert capture and attenuation of a hippocampus-dependent fear memory. Nat. Neurosci. 2021, 24, 677-684. [CrossRef]

47. De Zeeuw, C.I.; Lisberger, S.G.; Raymond, J.L. Diversity and dynamism in the cerebellum. Nat. Neurosci. 2021, $24,160-167$. [CrossRef] [PubMed]

48. Welniarz, Q.; Worbe, Y.; Gallea, C. The Forward Model: A Unifying Theory for the Role of the Cerebellum in Motor Control and Sense of Agency. Front. Syst. Neurosci. 2021, 15. [CrossRef] [PubMed]

49. Jankovic, J. Parkinson's disease: Clinical features and diagnosis. J. Neurol. Neurosurg. Psychiatry 2008, 79, 368-376. [CrossRef]

50. Zhao, N.; Yu, M.J.; Xu, J.; Wang, H.Y.; Liang, B.; Ding, L.; Leng, B.L. MicroRNA-29b mediates Th17/Treg imbalance in chronic obstructive pulmonary disease by targeting IL-22. J. Biol. Regul. Homeost. Agents 2021, 35, 987-999. [PubMed]

51. Min, H.K.; Won, J.Y.; Kim, B.M.; Lee, K.A.; Lee, S.J.; Lee, S.H.; Kim, K.W. Interleukin (IL)-25 suppresses IL-22-induced osteoclastogenesis in rheumatoid arthritis via STAT3 and p38 MAPK/IkappaBalpha pathway. Arthritis Res. Ther. 2020, 22, 222. [CrossRef]

52. Meng, J.; Chen, F.-R.; Yan, W.-J.; Lin, Y.-K. MiR-15a-5p targets FOSL1 to inhibit proliferation and promote apoptosis of keratinocytes via MAPK/ERK pathway. J. Tissue Viability 2021, 30, 544-551. [CrossRef]

53. Zhang, H.; Chen, M.; Liu, Y.; Dong, X.; Zhang, C.; Jiang, H.; Chen, X. Paroxetine combined with fluorouracil plays a therapeutic role in mouse models of colorectal cancer with depression through inhibiting IL-22 expression to regulate the MAPK signaling pathway. Exp. Ther. Med. 2020, 20, 240. [CrossRef] [PubMed]

54. Suzuki, K.; Suzuki, S.; Ishii, Y.; Okamura, M.; Matsubara, T.; Fujita, H.; Nozawa, N.; Kobayashi, S.; Hirata, K. Plasma prostaglandin D2 synthase levels in sleep and neurological diseases. J. Neurol. Sci. 2020, 411, 116692. [CrossRef] [PubMed]

55. López, D.E.; Ballaz, S.J. The Role of Brain Cyclooxygenase-2 (Cox-2) Beyond Neuroinflammation: Neuronal Homeostasis in Memory and Anxiety. Mol. Neurobiol. 2020, 57, 5167-5176. [CrossRef]

56. Cervellati, C.; Trentini, A.; Pecorelli, A.; Valacchi, G. Inflammation in Neurological Disorders: The Thin Boundary Between Brain and Periphery. Antioxidants Redox Signal. 2020, 33, 191-210. [CrossRef] [PubMed]

57. Wu, Y.; Zhang, H.; Wang, C.; Broekman, B.F.P.; Chong, Y.-S.; Shek, L.P.; Gluckman, P.D.; Meaney, M.J.; Fortier, M.V.; Qiu, A. Inflammatory modulation of the associations between prenatal maternal depression and neonatal brain. Neuropsychopharmacology 2020, 46, 470-477. [CrossRef] 
58. Ferrucci, V.; Asadzadeh, F.; Collina, F.; Siciliano, R.; Boccia, A.; Marrone, L.; Spano, D.; Carotenuto, M.; Chiarolla, C.M.; De Martino, D.; et al. Prune-1 drives polarization of tumor-associated macrophages (TAMs) within the lung metastatic niche in triple-negative breast cancer. iScience 2020, 24, 101938. [CrossRef] [PubMed]

59. Magee, J.C.; Grienberger, C. Synaptic Plasticity Forms and Functions. Annu. Rev. Neurosci. 2020, 43, 95-117. [CrossRef]

60. Freedman, A.; Jacobsen, E. Follicular lymphoma: 2020 update on diagnosis and management. Am. J. Hematol. 2019, 95, 316-327. [CrossRef]

61. Canizal-García, M.; Olmos-Orizaba, B.E.; Moreno-Jiménez, M.; Calderón-Cortés, E.; Saavedra-Molina, A.; Cortés-Rojo, C. Glutathione peroxidase 2 (Gpx2) preserves mitochondrial function and decreases ROS levels in chronologically aged yeast. Free Radic. Res. 2021, 55, 165-175. [CrossRef] [PubMed]

62. Ennerfelt, H.E.; Lukens, J.R. The role of innate immunity in Alzheimer's disease. Immunol. Rev. 2020, 297, 225-246. [CrossRef] [PubMed]

63. Daily, J.W.; Kang, S.; Park, S. Protection against Alzheimer's disease by luteolin: Role of brain glucose regulation, antiinflammatory activity, and the gut microbiota-liver-brain axis. Biofactors 2021, 47, 218-231. [CrossRef] [PubMed]

64. Shahdadi, S.H.; Jebali, A.; Iman, M. Dual function of interleukin-23 Aptamer to suppress brain inflammation via attachment to macrophage stimulating 1 kinase and interleukin-23. Colloids Surf. B Biointerfaces 2020, 185, 110619. [CrossRef] 